\title{
Life insurance and genetic test results: a mutation carrier's fight to achieve full cover
}

Louise A Keogh BSc, MA, PhD, Senior Lecturer ${ }^{1}$

\section{Margaret FA Otlowski} LLB(Hons), PhD, Dean and Professor of $\mathrm{Law}^{2}$

ICentre for Women's Health, Gender and Society, University of Melbourne, Melbourne, VIC.

2 University of Tasmania, Hobart, TAS.

l.keogh@unimelb.edu.au

doi: $10.5694 /$ mjal3.10202
A s well as evidence that individuals who have undergone genetic testing are concerned about life insurance discrimination, ${ }^{1}$ there is evidence that the fear of such discrimination can act as a deterrent to genetic testing. ${ }^{2}$ In addition, in Australia and the United Kingdom, there is evidence that life insurance companies have made incorrect risk-assessment judgements based on genetic information. ${ }^{3,4}$ There is ongoing debate about the need for reform in order to address these issues. ${ }^{5}$

Australian life insurers are permitted to use an applicant's genetic information to assess applications for life insurance. This is based on an exemption under s 46 of the Disability Discrimination Act 1992 (Cwlth), which prohibits disability discrimination, including discrimination against people on the basis of their genetic status (disability is defined in s 4 of the Act). Unlike health insurance, which is community rated, underwriting for life insurance involves assessing individual risk, and applicants have a duty to fully disclose all health information relevant to the insurer. However, to come within the scope of the legislative exemption, life insurance companies need to be able to provide actuarial or statistical data to justify their underwriting decisions. Further, under Financial Services Council (FSC) Standard No. 11, the industry standard on genetic testing, life insurers cannot request that an applicant undergo genetic testing. ${ }^{6}$ They may request that all existing genetic test results be made available to the insurer for the purposes of classifying the risk. This concept of the insurer having relevant information that is available to the applicant is seen as important to avoid "adverse selection". Paragraph 10.5 of the FSC Standard provides that insurers will take into account the benefits of special medical surveillance, early medical intervention and the likelihood of successful treatment. ${ }^{6}$

The Australian law in this area was reviewed as part of the Australian Law Reform Commission (ALRC) and Australian Health Ethics Committee inquiry into the protection of human genetic information. ${ }^{7}$ While recognising the concerns raised by the use of genetic information in underwriting life insurance, the inquiry found that "a shift away from the fundamental principles of voluntary mutually rated insurance, based on parity of information between the applicant and the insurer, is not justified at the present time". ${ }^{7}$ Although noting that life insurance plays an important role, the inquiry observed that it is not seen as an "essential good" and, in practice, only about a third of the Australian population has life insurance. The inquiry argued that genuine concerns about insurers' use of genetic information in underwriting could be addressed without departing from the existing principle of parity of information between the applicant and the insurer. In doing

\section{Sunnery}

- Currently, there is debate about life insurance companies' use of genetic information for assessing applicants.

- In his early 20s, James (pseudonym) was denied full life insurance cover because he revealed that he had discussed genetic testing with a genetic counsellor. He was later tested and found to carry a mutation in the MSH6 gene; after disclosing this, he was denied cover for cancer by two other life insurance companies.

- Unsatisfied with the insurance companies' risk assessments, and based on his understanding that regular colonoscopy significantly reduced his risk of cancer, James made a complaint to the Australian Human Rights Commission. After informing the third insurance company that he had done so, he was offered full coverage, which suggests that the company did not have actuarial data to justify its decision.

- This case provides evidence of the high level of initiative and proactivity required for a consumer to achieve a fair result. Few Australians would be in a position to pursue the level of research and advocacy undertaken by James (a professional with scientific training).

- We call on a collaborative approach between industry, government and researchers to address the issues that James's case raises about genetic testing and life insurance.

so, it addressed concerns raised on behalf of consumers, but also acknowledged the legitimate role of commercial insurance and the need to protect insurers from "adverse selection" if high-risk individuals could join at standard rates. This approach is perhaps not surprising, given the proactive role played by the peak life insurance body, the Investment and Financial Services Association (now the FSC), and its high level of cooperation with the inquiry. The inquiry recommended a number of reforms, with the aim of ensuring that the use of genetic information by insurers is fair and transparent and that insurers are kept to the terms of the exemption granted to them under the Disability Discrimination Act. A key aspect of the recommendations was the establishment of a process for ascertaining which genetic tests are sufficiently accurate and reliable for the purposes of use in life insurance underwriting (recommendations 27-1, 27-2 and 27-3). ${ }^{7}$ To date, these recommendations, which were central to the compromise solution reached, have not been implemented. Another relevant recommendation was that the reasons given to an applicant for an unfavourable underwriting decision based on genetic information must be clear and meaningful, and must explain the actuarial, statistical or other basis for the decision (recommendation 27-5). ${ }^{7}$ The ALRC 
also recommended that access be provided to reviews of underwriting decisions involving the use of genetic information (recommendation 27-9). ${ }^{7}$ These recommendations are also yet to be implemented. The stalling may be due to the way in which the inquiry framed the reforms, which were directed at government and the FSC. Implementation of the reforms requires cooperation from the life insurance industry, and there is little commercial incentive for the industry to promote the proposed changes.

Notably, some European countries have taken a more interventionist approach, legislating to prohibit the use of genetic tests by life insurers. ${ }^{8}$ This form of legislative prohibition is consistent with the Council of Europe's convention on human rights and biomedicine (http://conventions. coe.int/Treaty/en/Treaties/Html/164.htm), which prohibits genetic discrimination. In other countries, moratoria on the use of genetic tests have been in place as a means of regulating this area, typically as a short-term measure, although in the UK, a moratorium has been in place since 1997 and has recently been further extended to 2014. In the UK, genetic test results do not need to be disclosed to obtain policies under $£ 500000$ for life insurance and under $£ 300000$ for critical illness, income protection and long-term care insurance. For policies above these thresholds, only the test for Huntington disease has been approved for use by insurers by the former Genetics and Insurance Committee.

In the United States, concerns about genetic discrimination have mostly centred on health insurance, due to the current absence of a universal health care system. This has led to the introduction of the Genetic Information Nondiscrimination Act 2008, which prohibits discrimination in health insurance cover and employment based on genetic information, but does not deal with life insurance.

\section{Case study}

We present a recent Australian case to explore the current issues regarding life insurance and genetics-related information in Australia.

James (pseudonym) was in his early 20s when he started receiving letters from a familial bowel cancer registry, run by a genetics service, recommending that he consider genetic testing for Lynch syndrome. Lynch syndrome (previously known as hereditary non-polyposis colorectal cancer) is an inherited cancer syndrome caused by a mutation in a mismatch repair gene. Compared with the general population, carriers have an increased risk of colorectal and other types of cancer, with an earlier age of onset. Colonoscopic screening significantly improves survival among carriers of Lynch syndrome. ${ }^{9}$ James's mother had been diagnosed with uterine cancer at 50 years of age. However, James was not particularly interested in undertaking a genetic test at this stage.

Several years later, he discussed genetic testing for Lynch syndrome with a doctor, who advised him to ensure that he had a life insurance policy first. James had an existing life insurance policy, which he had applied for when he started working. For this policy, he had declared his mother's uterine cancer. After a substantial increase in his salary, he applied for an increase in cover and was approved with no conditions. On the application form, there was a question asking whether he was planning to seek any medical advice, treatment or tests, to which he replied "no", notwithstanding the fact that he had made an appointment to see a genetic counsellor.

He then went to the genetics service to discuss testing. They gave him "a lot of information" and followed up with a letter, which "was very descriptive about ... what I discussed with the counsellor ... That got me a bit worked up because I thought this kind of thing was a conversation with a counsellor and wouldn't end up in official correspondence".

James was concerned that the written record of his discussion with the genetics service (including reference to a discussion about genetic testing) would render his insurance invalid. He disclosed all correspondence between himself and the genetics service to the insurance company. Based on this information, he was denied cover for cancer in his upgraded policy.

He decided to "just stick with the cover that I had when I initially applied as a graduate, as that includes everything", and he "left it at that for another couple of years".

After researching Lynch syndrome further, James recognised the need to test and potentially begin surveillance before 30 years of age. He underwent testing at 27 years of age and was found to carry a mutation in the MSH6 gene, a mutation associated with Lynch syndrome.

He applied to a second company for life insurance, disclosing his genetic test result. Once again, he was offered cover excluding cancer.

I left it for a little bit and then I thought to myself, "All right. I'm going to try someone else" ... I thought I'm going to get everything in writing and I'm not going to let them push me around ... I got all fired up and I did some research.

James read published epidemiological research articles and communicated with their authors. ${ }^{10,11}$ He worked out that his risk of colorectal cancer, if he underwent yearly colonoscopy, was the same as the population risk. He presented this in a lengthy document with his application to a third insurance company. He included a table of risks to illustrate that he should not be considered at higher risk of colorectal cancer if he adhered to yearly colonoscopy (Box).

He was once again denied cover for cancer.

I said to them, "Show me the actuarial evidence of why you can do this" ... they just ignored that request ... They wrote me some terrible letter saying that even though I'm getting this surveillance, it doesn't eliminate my risk of cancer, which is irrelevant. The relevant part is my level of risk of getting cancer compared with the general population.

James carried out further research and decided on a course of action. He made a complaint to the Australian Human Rights Commission, submitting all documentation between himself and the third life insurance company. Soon after informing the insurance company that he had made the complaint, he was offered full cover, with the minor exclusion of any claim caused as a result of a colonoscopy.

\section{Analysis}

At the time of James's application to the first life insurance company, he had discussed the possibility of genetic testing 


\begin{tabular}{|c|c|c|c|c|c|}
\hline \multicolumn{6}{|c|}{ Colorectal cancer risk for a 29-year-old man* } \\
\hline & Next 20 years & Next 30 years & Next 40 years & Next 45 years & Source \\
\hline Population risk & $0.3 \%$ & $1.3 \%$ & $3.5 \%$ & $6 \%$ & Dr Jones ${ }^{\dagger}$ \\
\hline $\begin{array}{l}\text { MSH6 carrier risk with no } \\
\text { screening }\end{array}$ & $1.8 \%$ & $6.7 \%$ & $18.9 \%$ & $\begin{array}{l}\text { Irrelevant because it is } \\
\text { beyond working age }\end{array}$ & Dr Jones; ${ }^{\dagger}$ Baglietto ${ }^{10}$ \\
\hline $\begin{array}{l}\text { MSH6 carrier risk with } \\
\text { colonoscopy every } 3 \text { years }\end{array}$ & $0.68 \%$ & $2.54 \%$ & $7.18 \%$ & $\begin{array}{l}\text { Irrelevant because it is } \\
\text { beyond working age }\end{array}$ & Dr Jones; ${ }^{\dagger}$ Baglietto; ${ }^{10}$ Järvinen" \\
\hline $\begin{array}{l}\text { MSH6 carrier risk with } \\
\text { annual colonoscopy }\end{array}$ & $0.36 \%$ & $1.3 \%$ & $3.78 \%$ & $\begin{array}{l}\text { Irrelevant because it is } \\
\text { beyond working age }\end{array}$ & Dr Jones; ${ }^{\dagger}$ Baglietto; ${ }^{10}$ Järvinen" \\
\hline
\end{tabular}

for Lynch syndrome with a doctor but had not undergone genetic testing. There was some family history information available, which he had disclosed. His application for increased cover was initially approved. It was only after he voluntarily disclosed his dealings with the genetic service after receiving correspondence from them that the insurer withdrew approval for the increased cover, alleging that he had failed to make full disclosure at the time of application. However, in terms of actuarial evidence, there was no new information on which this insurer could base its decision to exclude cancer from his insurance cover. Significantly, James did not have more information about his risk status than the insurer, and the advice from his doctor, quite appropriately, had been to get his life insurance in order before undertaking genetic testing. Viewed objectively, this decision was not justified by any actuarial or statistical data and amounted to unlawful discrimination outside the scope of the insurance exemption. At most, this may have justified postponing the processing of the application to ascertain whether James would proceed with genetic testing. It certainly did not justify the insurer's decision to exclude for cancer cover and, in the absence of any relevant evidence, the decision was clearly inappropriate.

By the time of James's second and third insurance applications, his circumstances had changed, as he had undergone a genetic test and was found to carry a mutation in the MSH6 gene, which had implications for his risk status. In these further applications for life insurance cover, James fully disclosed his genetic test result. In both instances, the insurance companies offered restricted cover that excluded cancer.

The difference between the second and third insurance applications was that, in the latter, James challenged the decision and presented information demonstrating that, with regular surveillance, he presented no greater risk than the average population risk. Given the need for insurers to have actuarial or statistical data to justify their decisions under the insurance exemption (s 46 of the Disability Discrimination Act), and the requirement that insurers take into account the benefits of special medical surveillance (para 10.5 of the FSC Standard), the restricted cover offered in response to James's third insurance application was clearly not justified. Notably, James initially asked the insurer on what actuarial evidence they had relied, but "they had just ignored that request". Yet, legally, insurers bear the onus of proof in order to have the benefit of the insurance exemption. This harks back to ALRC recommendation 27-5, which affirms the need to provide an applicant with clear reasons for an unfavourable decision based on genetic information, explaining its actuarial, statistical or other basis. The insurer's backdown following James's advice that he had lodged a complaint with the Human Rights Commission further supports this conclusion, suggesting that the insurer did not believe that it would be able to justify the decision to exclude cover for cancer. While the insurer's final decision was an appropriate one, it was only reached as a result of James's tenacity in pressing for a decision based on the best available evidence. In this respect, James is not a typical consumer. His case highlights the difficulties for people who are less able to undertake their own research and present a compelling case. ${ }^{12}$ It was only because of the requirement that insurers bear the burden of proof in relation to their risk-assessment decisions that James was able to achieve his result. However, it is discouraging that it was only when a legal threat was applied that the requirement had any impact in this case. It seems quite unreasonable that, in practice, the onus is on the applicant to have unjustifiable life insurance decisions overturned.

\section{Conclusion}

This case study adds to the evidence that incorrect risk estimates are being used by the insurance industry. ${ }^{13,3}$ Although, ultimately, the applicant was able to increase his life insurance cover without a cancer exclusion, the case highlights the high levels of initiative and effort potentially required for a consumer to achieve a fair result. This case involved three insurance companies, all acting in a similar way. In the absence of any exceptional circumstances (other than James's tenacity), we believe it provides good evidence of the risk of improper treatment of mutation carriers by the life insurance industry in the current legal environment. Realistically, few Australians would be in a position to pursue the level of research and advocacy undertaken by James, a professional with scientific training. Although, legally, life insurers bear the onus of demonstrating that they have data on which they can reasonably rely to make an adverse finding based on genetic information, this case illustrates how, in practice, consumers are largely powerless unless they proactively enforce this onus by bringing or threatening proceedings under antidiscrimination legislation. This is clearly an unsatisfactory situation. We already have evidence that life insurance concerns can act as a deterrent to genetic testing, ${ }^{2}$ potentially reducing the benefits to individuals and society of appropriate identification and management of inherited cancer predispositions. We call for a collaborative approach between industry, 
government and researchers to address insurance industry practice, government policy and the adequacy of the current legal framework. If a satisfactory solution, protecting consumer interests, cannot be achieved through a collaborative approach, then a review of the compromise reached in the ALRC inquiry may be warranted.

Acknowledgement: We thank James (pseudonym) for his cooperation in presenting the details of his case.

Competing interests: No relevant disclosures.

Provenance: Not commissioned; externally peer reviewed

1 Bombard Y, Palin J, Friedman JM, et al. Beyond the patient: the broader impact of genetic discrimination among individuals at risk of Huntington disease. Am J Med Genet B Neuropsychiatr Genet 2012; 159B: 217-226.

2 Keogh LA, van Vliet CM, Studdert DM, et al. Is uptake of genetic testing for colorectal cancer influenced by knowledge of insurance implications? Med J Aust 2009; 191: 255-258

3 Barlow-Stewart K, Taylor SD, Treloar SA, et al. Verification of consumers' experiences and perceptions of genetic discrimination and its impact on utilization of genetic testing. Genet Med 2009; 11: 193-201.

4 Mould A. Implications of genetic testing: discrimination in life insurance and future directions. J Law Med 2003; 10: 470-487.

\section{URGENT WARNING!}

Dear MJA readers,

Please take heed of the sad case of Dr Smith: he completely lost the plot after realising that he had missed last year's MJA Christmas Competition deadline.

\section{It's not too late for you.}

If you start foaming at the mouth, laughing uncontrollably or having three-way conversations with yourself, then drop everything and

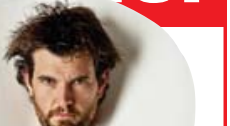
enter the MJA Christmas Competition.

Let our readers share the experience of your unusual and humorous medical stories. Send us your seriously funny research, strange images, cartoons, quirky quips and gory stories. You can win great prizes AND be published in the MJA, Australia's premier medical journal.

\section{Entries close Friday 11 October 2013}

\section{For full submission details visit:}

https://www.mja.com.au/author-centre/awards/ mja-christmas-competition

\section{Contact our Editorial Administrator: phone 0295626666}

\section{Visit last year's winners at:}

https://www.mja.com.au/Journal/2012/197/11/

earth-peace-and-good-will-and-fair-go-all
5 Joly Y, Ngueng Feze I, Simard J. Genetic discrimination and life insurance: a systematic review of the evidence. BMC Med 2013; 11: 25.

6 Financial Services Council. Genetic Testing Policy. FSC Standard No. 11. December 2005. http://www.fsc.org.au/downloads/file/ FSCStandards/11S_GeneticTestingPolicy.pdf (accessed Aug 2013).

7 Australian Law Reform Commission, Australian Health Ethics Committee. Essentially yours: the protection of human genetic information in Australia. (ALRC Report 96.) Sydney: ALRC, 2003. http://www.alrc.gov.au/ publications/report-96 (accessed Jul 2013).

8 Otlowski M, Taylor S, Bombard Y. Genetic discrimination: international perspectives. Annu Rev Genomics Hum Genet 2012; 13: 433-454.

9 Lynch HT, Lynch JF, Attard TA. Diagnosis and management of hereditary colorectal cancer syndromes: Lynch syndrome as a model. CMAJ 2009; 181: 273-280.

10 Baglietto L, Lindor NM, Dowty JG, et al. Risks of Lynch syndrome cancers for MSH6 mutation carriers. J Natl Cancer Inst 2010; 102: 193-201.

11 Järvinen HJ. Hereditary cancer: guidelines in clinical practice. Colorectal cancer genetics. Ann Oncol 2004; 15 Suppl 4: ivl27-iv131.

12 Otlowski M, Taylor S, Barlow-Stewart K, et al. The use of legal remedies in Australia for pursuing allegations of genetic discrimination: findings of an empirical study. Int J Discrim Law 2007; 9: 3-35. doi: 10.1177/135822910700900102.

13 Otlowski M, Barlow-Stewart K, Taylor S, et al. Investigating genetic discrimination In the Australian life insurance sector: the use of genetic test results in underwriting, 1999-2003. J Law Med 2007: 14: 367-396.

\section{Stamps of greatness}

\section{Anna Heer (1863-1918)}

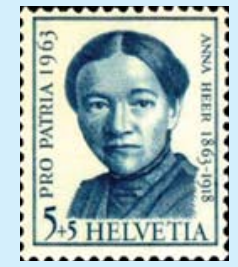

Dr AnNa Heer was born on 22, March 1863 in Olten, Solothurn Canton, Switzerland. In 1880 she went to Zurich to study art but soon changed to medicine.

In 1892 she became a Doctor of Medicine of the University of Zurich. Subsequently she performed postgraduate work in gynaecology, obstetrics and public health in several German and English hospitals and universities

On her return to Zurich she practised medicine and also taught hygiene at the local girls' high school. While practising, she became aware of the lack of competent nurses and decided to found a school and training hospital for nurses.

She was actively supported in this work by the Swiss women's clubs and a few other women physicians. The cornerstone for the institution was laid in 1899 and the school was opened in Zurich in 1901. She served as its first director and physician-inchief until her death in 1918. During these years she became internationally known for her efficiency and dedication.

She died in Zurich on 19, December, 1918, a victim of the influenza epidemic sweeping the world.

Philatelically she was honoured by her country in 1963 as an outstanding physician and as the founder of the first Swiss nursing school. Incidentally, she is the first woman physician to be honoured as such on an official stamp.

AMA Gazette 1977; Jan

John Roche

This is an edited version of a series that first appeared in the 